\title{
Temperature-dependent erosivity of drinks in a model simulating oral fluid dynamics
}

\begin{abstract}
Steiger-Ronay, Valerie ; Steingruber, Andrea ; Becker, Klaus ; Aykut-Yetkiner, Arzu ; Wiedemeier, Daniel B ;
\end{abstract} Attin, Thomas

\begin{abstract}
OBJECTIVES Aim of this investigation was to study the temperature-dependent in vitro enamel erosion of five acidic drinks and citric acid under controlled conditions in an artificial mouth. METHODS The erosive potential of Orange juice, Coca-Cola Zero, Sprite Zero, two fruit teas and citric acid (control) was investigated on bovine enamel specimens at temperatures between $5{ }^{\circ} \mathrm{C}$ and $55^{\circ} \mathrm{C}$. The $\mathrm{pH}$ values and total calcium content of all test drinks were determined. Specimens were immersed into an artificial mouth to imitate physiological oral conditions for $60 \mathrm{~h}$. Cyclic de- and re-mineralization was performed, imitating the intake of six drinks in six $\mathrm{h}$ followed by a six-hour remineralization phase, where only artificial saliva ran over the specimens. Total erosive enamel loss was determined by contact profilometry. Differences in substance loss at different temperatures were tested for statistical significance ( $\mathrm{p}$-values $\leq 0.05$ ) by means of ANOVA. RESULTS Rising liquid temperature did not result in a considerable change of $\mathrm{pH}$. Highest substance loss was observed for citric acid $(33.6 \pm 6 \mu \mathrm{m}$ to $38.7 \pm 6 \mu \mathrm{m})$, while only little erosion was induced by fruit tea $(0.8 \pm 1 \mu \mathrm{m}$ to $5.9 \pm 1 \mu \mathrm{m})$. Rising liquid temperature did not result in significantly increased substance loss for citric acid, orange juice and Coca-Cola Zero. Sprite Zero and both fruit teas, however, caused significantly $(\mathrm{p}<0.001)$ more enamel loss at elevated temperature. CONCLUSIONS Not all investigated drinks showed a temperature-induced change in erosivity. CLINICAL SIGNIFICANCE For some erosive beverages it can be recommended to keep the consummation temperature as low as possible to decrease the risk of erosive tooth substance loss.
\end{abstract}

DOI: https://doi.org/10.1016/j.jdent.2018.01.002

Posted at the Zurich Open Repository and Archive, University of Zurich

ZORA URL: https://doi.org/10.5167/uzh-167762

Journal Article

Accepted Version

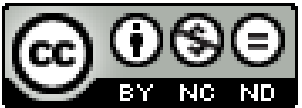

The following work is licensed under a Creative Commons: Attribution-NonCommercial-NoDerivatives 4.0 International (CC BY-NC-ND 4.0) License.

Originally published at:

Steiger-Ronay, Valerie; Steingruber, Andrea; Becker, Klaus; Aykut-Yetkiner, Arzu; Wiedemeier, Daniel B; Attin, Thomas (2018). Temperature-dependent erosivity of drinks in a model simulating oral fluid dynamics. Journal of Dentistry, 70:118-123.

DOI: https://doi.org/10.1016/j.jdent.2018.01.002 


\section{Temperature-dependent erosivity of drinks in a model simulating oralfluiddynamics}

Valerie Steiger-Ronay ${ }^{\mathrm{a}}$, , Andrea Steingruber ${ }^{\mathrm{a}}$, Klaus Becker ${ }^{\mathrm{a}}$, Arzu Aykut-Yetkiner ${ }^{\mathrm{b}}$, Daniel B. Wiedemeier ${ }^{\mathrm{c}}$, Thomas Attin ${ }^{\mathrm{a}}$

${ }^{a}$ Clinic of Preventive Dentistry, Periodontology and Cariology, Center of Dental Medicine, University of Zurich, Plattenstrasse 11, 8032 Zurich, Switzerland

${ }^{b}$ University of Ege, Faculty of Dentistry, Department of Pedodontics, Gençlik Cad., No: 12, 35040 Bornova,İzmir, Turkey

'Statistical Services, Center of Dental Medicine, University of Zurich, Plattenstrasse 11, 8032 Zurich, Switzerland

\section{Abstract \\ Temperature-dependent erosivity of drinks in a model simulating oral fluid dynamics Objectives}

Aim of this investigation was to study the temperature-dependent in vitro enamel erosion of five acidic drinks and citric acid under controlled conditions in an artificial mouth.

\section{Methods}

The erosive potential of Orange juice, Coca-Cola Zero, Sprite Zero, two fruit teas and citric acid (control) was investigated on bovine enamel specimens at temperatures between $5{ }^{\circ} \mathrm{C}$ and $55{ }^{\circ} \mathrm{C}$. The $\mathrm{pH}$ values and total calcium content of all test drinks were determined. Specimens were immersed into an artificial mouth to imitate physiological oral conditions for 60 h. Cyclic de- and re-mineralization was performed, imitating the intake of six drinks in six $\mathrm{h}$ followed by a six-hour remineralization phase, where only artificial saliva ran over the specimens. Total erosive enamel loss was determined by contact profilometry. Differences in substance loss at different temperatures were tested for statistical significance ( $p$-values $\leq$ $0.05)$ by means of ANOVA.

\section{Results}

Rising liquid temperature did not result in a considerable change of $\mathrm{pH}$. Highest substance loss was observed for citric acid $(33.6 \pm 6 \mu \mathrm{m}$ to $38.7 \pm 6 \mu \mathrm{m})$, while only little erosion was 
induced by fruit tea $(0.8 \pm 1 \mu \mathrm{m}$ to $5.9 \pm 1 \mu \mathrm{m})$. Rising liquid temperature did not result in significantly increased substance loss for citric acid, orange juice and Coca-Cola Zero. Sprite Zero and both fruit teas, however, caused significantly $(p<0.001)$ more enamel loss at elevated temperature.

\section{Conclusions}

Not all investigated drinks showed a temperature-induced change in erosivity.

\section{Clinical Significance}

For some erosive beverages it can be recommended to keep the consummation temperature as low as possible to decrease the risk of erosive tooth substance loss. 


\section{Introduction}

Dental erosion is defined as a loss of tooth substance by chemical processes without involvement of bacteria [1]. Erosive tooth wear is on the rise, affecting between $4 \%$ and up to $100 \%$ of adults examined, depending on the population studied and the examination standard used [2]. Furthermore, prevalence of erosion increases, especially among younger age groups [3-6]. Parallel to this development, a globally increasing consumption of soft drinks has been observed [7]. While high soft drink consumption is associated with overweight, obesity and diabetes [8-10], it is also affecting dental health due to an increased risk for dental caries [11] and dental erosion $[8,12,13]$. Furthermore, erosion that is caused by beverages has not only been linked to the consumption of acidic carbonated drinks, but also to the intake of fruit juices, acidic sports drinks, wines, cider and acidic herbal teas [14].

Apart from frequency and timing of intake, the erosive effect of acidic beverages is also influenced by factors including type and concentration of acid, $\mathrm{pH}$ value, amount of titratable acid and buffer capacity $[15,16]$. Since most chemical reactions are affected by temperature, it was hypothesized that the consumption of hot erosives results in increased enamel loss. Several studies confirmed this assumption by finding increasing erosive action of liquids with rising temperature [17-20]. The influence of the temperature of erosive drinks in interaction with the remineralizing action of saliva, however, has rarely been investigated. Saliva is one of the most relevant factors for the prevention and development of dental erosion. It develops its protective properties by (1) diluting and clearing of acid, (2) neutralizing and buffering of acid, (3) by formation of the acquired pellicle through adsorption of salivary proteins and glycoproteins, which protect the enamel surface from demineralization and (4) by providing calcium, phosphate and fluoride necessary for maintaining a supersaturated state close to the tooth surface and for rehardening of eroded tooth substance [14, 21-23]. The relevance of saliva and its flow rate on the initiation and magnitude of erosion was shown experimentally, as well in clinical studies $[24,25]$. Patients with reduced salivary flow rate or reduced buffering capacity are particularly susceptible to erosive tooth loss [26].

Individual drinking habits determine the contact time between acidic agens and tooth substance, the liquid flow rate and of course the localization of erosive action [27-30]. Therefore, erosion may not only be prevented by reducing the consumption of acidic foods and beverages but also through alteration of the drinking habits [29, 31]. Beverage temperature would be one of the factors that can be modified. 
Consequently, the aim of the present investigation was to study the temperature-dependent in vitro bovine enamel erosion of five differently tempered beverages in interaction with remineralizing action of artificial saliva under controlled conditions in an artificial mouth.

\section{Materials and Methods}

\section{Experimental procedure}

Figure 1 schematically illustrates the experimental procedure. The temperature-dependent erosive potential of five beverages and citric acid (control) was investigated at temperatures between $5{ }^{\circ} \mathrm{C}$ and $55{ }^{\circ} \mathrm{C}$. This set-up resulted in 16 test groups with twelve independent enamel specimens each. Contact profilometry was used to determine the erosive substance loss. After initial profilometry, specimens were immersed in the artificial mouth for $60 \mathrm{~h}$, corresponding to 5 days with a respective duration of $12 \mathrm{~h}$. During these $12 \mathrm{~h}$, cyclic de- and re-mineralization was performed to imitate the intake of six drinks in six h followed by a sixhour remineralization phase, during which only artificial saliva ran over the samples.

After completion of the $60 \mathrm{~h}$ of experiment, final profilometry was performed. Total erosive enamel loss was determined by calculating the difference between baseline and final profiles.

\section{Enamel specimen preparation}

Enamel specimens were obtained from intact bovine incisors. After separation of the crown from the root, a water-cooled diamond core drill was used to prepare enamel samples with a diameter of $3 \mathrm{~mm}$ out of the labial tooth surfaces. Thereafter, specimens were embedded in acrylic resin blocks (Paladur, Heraeus Kulzer, Hanau, Germany). Enamel surfaces were ground with water-cooled silicon carbide paper discs (\# 1000, \# 2000, \# 4000; Struers, Birmensdorf, Switzerland). A notch was placed in all samples to enable exact repositioning for the profilometric measurements.

\section{Artificial mouth}

All samples were submitted to alternating episodes of de- and remineralization in a so-called artificial mouth, which was described in detail previously [32]. This special custom-made setup was constructed to imitate physiological oral conditions. Hereby, the twelve specimens per group were centrally placed in a superfusion chamber at a constant temperature of $37^{\circ} \mathrm{C}$. The system further consisted of two electric pumps (IPC, Ismatec; Cole-Parmer GmbH, Wertheim, Germany), which supplied the specimens with artificial saliva (pump 1) or the tempered test drink (pump 2) through individual tubes via 12-channel T-tube connector. Test liquids were 
stored at the required temperature in an isolated tank, which was controlled by a thermostat (Julabo F25, Julabo GmbH, Seelbach, Germany). Furthermore, test liquids were permanently pumped through the system to ensure the stability of the desired temperature level throughout the experiment. Liquid flow rate $(280 \mathrm{~mm} / \mathrm{min})$, as well as the valve assembly controlling the intermittent alternation of erosive test liquids and artificial saliva were controlled by custom designed software (PPK laboratory, University of Zurich, Switzerland). Pump 1 was programmed to constantly supply the specimens with artificial saliva. Only during the demineralization phase the valve assembly was programmed to switch from pump 1 to pump 2, which now provided the specimens with tempered test liquid. Each of the six simulated drinks was taken in 10 "sips", with one "sip" lasting for 10 seconds, followed by 50 seconds of clearance with artificial saliva. This set-up should represent the consummation of one drink in $10 \mathrm{~min}$. For the following $50 \mathrm{~min}$, only artificial saliva was circulated over the samples for remineralization. This sequence was repeated for 6 times (representing the consummation of six drinks in six h), followed by six h of remineralization with saliva (see Figure 1).

\section{Artificial Saliva}

Artificial saliva was prepared freshly every day. The composition of saliva was prepared as follows [mmol/1]: $\mathrm{NaCl}$ : 9.92; $\mathrm{CaCl}_{2}: 1.53 ; \mathrm{NH}_{4} \mathrm{Cl}: 2.99 ; \mathrm{KCl}: 17.0 ; \mathrm{NaSCN}: 1.97 ; \mathrm{KH}_{2} \mathrm{PO}_{4}$ : 2.42; $\mathrm{CO}\left(\mathrm{NH}_{2}\right)_{2}: 3.33 ; \mathrm{Na}_{2} \mathrm{HPO}_{4}: 2.40$ [33]. The $\mathrm{pH}$ value was 6.4. Artificial saliva was supplied to the enamel samples via individual tubes, which were fed by pump 1 from the storage tank.

\section{Test liquids}

Following beverages were investigated at different temperatures: Orange Juice (EckesGranini Suisse S.A., Henniez, Switzerland), Coca-Cola Zero (Coca-Cola HBC Switzerland AG, Brüttisellen, Switzerland) and Sprite Zero (Coca-Cola HBC Switzerland AG, Brüttisellen, Switzerland) were tested at the temperatures of $5{ }^{\circ} \mathrm{C}$ and $20{ }^{\circ} \mathrm{C}$, whereas fruit tea 1 ("Fruit tea", Twinings of London"TM, Wander AG, Neuenegg, Switzerland; Ingredients: hibiscus, natural cranberry, pomegranate and strawberry flavour, $29 \%$ other natural flavors, apple pieces, rosehip and sweet wood) and fruit tea 2 ("Fruit tea Strawberry, Raspberry and Rhubarb", Lipton ${ }^{\circledR}$, Unilever Deutschland GmbH, Hamburg, Germany; Ingredients: hibiscus, apple, flavor, rosehip, sweet wood, 2\% strawberry, 2\% raspberry, 2\% rhubarb and maltodextrin) were tested at $20{ }^{\circ} \mathrm{C}, 37{ }^{\circ} \mathrm{C}$ and $55{ }^{\circ} \mathrm{C}$. Citric acid served as control, and was investigated at all temperatures $\left(5^{\circ} \mathrm{C}, 20^{\circ} \mathrm{C}, 37^{\circ} \mathrm{C}\right.$ and $\left.55^{\circ} \mathrm{C}\right)$. 
Fruit teas were prepared according to the package instructions. One tea bag was used per $200 \mathrm{ml}$ of boiling hot water. The brewing time was set to five min. In order to avoid air bubbles disturbing the tube system, the originally carbonated drinks Coca-Cola Zero and Sprite Zero were decarbonated through shaking and use of a magnetic stirrer (IKA, Staufen im Breisgau, Germany) for a few minutes until the degassing process was finished. Further, the orange juice was centrifuged with $3000 \mathrm{rpm}$ for three min (Hermle, Gosheim, Germany) to remove larger suspended particles that could have blocked the system.

The $\mathrm{pH}$ values of all liquids were determined at the tested temperatures ( $\mathrm{pH}$-meter 827; Methrom, Herisau, Switzerland). In addition, total calcium content was evaluated (atomic absorption spectroscopy, contrAA® 300, Analytik Jena AG, Jena, Germany) as described elsewhere [34]. Furthermore, all beverages were titrated (686 Titroprocessor and 665 Dosimat, Metrohm Schweiz AG, Herisau, Switzerland) at room temperature with $0.1 \mathrm{M}$ $\mathrm{NaOH}$ solution to $\mathrm{pH} 5.5$ for determination of the titrable acid.

\section{Profilometry}

Erosive substance loss was investigated by contact profilometry (Perthometer S2; Mahr, Göttingen, Germany). The stylus tip of the profilometer had a diameter of $2 \mu \mathrm{m}$, and moved with a speed of $0.13 \mathrm{~mm} / \mathrm{s}$. Five profiles with a set distance of $250 \mu \mathrm{m}$ between each profile were recorded before (baseline profiles) and after the experiments (final profiles). A custommade jig ensured the reproducible positioning of the samples. After completion of the experiments, the exact superimposition of the baseline and respective final profiles was performed with custom designed software (4D Client, Custom designed software; University of Zurich, Switzerland) to calculate the average loss of substance per profile [35].

\section{Statistical analysis}

For the descriptive statistics, the means and standard deviations of the substance loss for all liquids and tested temperatures were calculated. Differences in substance loss at different temperatures within each beverage were tested statistically by means of ANOVA, as assumptions of homogeneity and normality of errors were not critically violated. Differences with a p-value of $\leq 0.05$ were considered statistically significant. Pairwise posthoc comparisons within each beverage group at different temperatures were calculated using Tukey's Honest Significance Difference Test. The statistical software R was used for the entire analysis [36]. 


\section{Results}

Table 1 presents the main active acids of the liquids, their $\mathrm{pH}$ values at all investigated temperatures, as well as their calcium values and titrable acidity at $20{ }^{\circ} \mathrm{C}[\mathrm{mmol} / \mathrm{L}]$. No considerable change of $\mathrm{pH}$ was found with rising liquid temperature. Neither decarbonation of the soft drinks nor centrifugation of the orange juice had an effect on the described values (data not shown).

Figure 2 shows the enamel loss caused by the examined liquids at the investigated temperatures after $60 \mathrm{~h}$ of experiment. Irrespective of liquid temperature, highest substance loss was observed for citric acid (Mean \pm standard deviation of $33.6 \pm 6 \mu \mathrm{m}$ to $38.7 \pm 6 \mu \mathrm{m}$ ), while only little erosion could be found in the fruit tea-treated specimens $(0.8 \pm 1 \mu \mathrm{m}$ to $5.9 \pm$ $1 \mu \mathrm{m})$. When studying the temperature-dependent erosive potential, heterogeneous results were found (Figure 2). Citric acid, which was used as control, did result in rising substance loss at elevated temperature but this difference was not significant $(p=0.341)$ for any of the tested temperatures. The latter was also true for orange juice and for Coca-Cola Zero, whose substance losses at $5{ }^{\circ} \mathrm{C}$ and $20{ }^{\circ} \mathrm{C}$ did not differ significantly. Sprite Zero, however, was significantly more erosive $(\mathrm{p}<0.001)$ at $20{ }^{\circ} \mathrm{C}$ than at $5{ }^{\circ} \mathrm{C}$. Furthermore, both fruit teas caused significantly $(\mathrm{p}<0.001)$ more substance loss at higher temperatures. Fruit tea 1 was significantly more erosive at $37^{\circ} \mathrm{C}$ and $55^{\circ} \mathrm{C}$ than at $20^{\circ} \mathrm{C}$, whereas no significant difference could be found between the two higher temperatures. Fruit tea 2 showed a slightly different pattern, being most erosive at $55^{\circ} \mathrm{C}$, while substance losses at $20^{\circ} \mathrm{C}$ and $37{ }^{\circ} \mathrm{C}$ did not differ significantly.

\section{Discussion}

The present study aimed to analyze the erosive effect of common beverages in dependence of their temperature. Heterogeneous results were found. For citric acid, orange juice and CocaCola Zero substance loss did not change significantly with rising temperature, while Sprite Zero and both fruit teas were significantly more erosive at higher temperatures.

In order to simulate physiological oral conditions during sipping of a beverage as well as possible, a customized artificial mouth set-up was utilized. Enamel samples were subjected to reproducible erosive attacks in alternation with repeated remineralization with artificial saliva. This fact could explain the deviating results of the present study in comparison to other publications examining this matter. Two in vitro studies, which investigated the influence of temperature on the erosivity of citric acid, found significantly increasing erosion with rising 
acid temperature at $5{ }^{\circ} \mathrm{C}, 35^{\circ} \mathrm{C}$ and $60{ }^{\circ} \mathrm{C}(\mathrm{p}<0.05)[18]$ and $4{ }^{\circ} \mathrm{C}, 20^{\circ} \mathrm{C}, 35^{\circ} \mathrm{C}$ and $50{ }^{\circ} \mathrm{C}(\mathrm{p}$ $<0.05)$ [19]. This finding is in contrast to the results of the present investigation, which only found a trend towards more erosion with higher temperatures for citric acid. Due to the present inclusion of the remineralizing effect of saliva, the constant temperature of $37{ }^{\circ} \mathrm{C}$ of the samples, and the simulation of oral fluid dynamics, however, the experimental set up cannot be compared.

Another investigation, which did analyze the effect of temperature on orange juice in interaction with cyclical exposure to artificial saliva, found significant $(\mathrm{p}<0.01)$ more erosion at $20{ }^{\circ} \mathrm{C}$ than at $4{ }^{\circ} \mathrm{C}$ [17], while the present study did not detect statistically different enamel loss at $5{ }^{\circ} \mathrm{C}$ and $20{ }^{\circ} \mathrm{C}$. In the cited study, however, specimens were immersed in stirred orange juice six times a day for five min, followed by rinsing with deionized distilled water and placement in artificial saliva. This set up resulted in a total of $30 \mathrm{~min}$ of exposure per day, and a total of $12 \mathrm{~h}$ of exposure to orange juice after the experimental duration of 24 days. One can argue, that with time one certainly reaches this degree of exposure to erosives, but it is not imitating average drinking behavior in sipping mode. The present study tried to follow a more realistic "real to life" scenario by imitating the sip-wise consumption of erosives followed by 50 seconds of saliva contact, resulting in a total contact time of ten min per day, which is already mimicking high-risk behavior.

Furthermore, in the cited studies specimens were immersed in acid for five min [17], ten min [18] and two $\mathrm{h}$ [19] respectively, with the consequence that specimens will have adopted the acid's temperature. This fact might have also contributed to the more distinct differences between the temperature groups. Of course in the present investigation superficial enamel layers will have also approximated the temperature of the test liquid during the ten seconds of demineralization. They will, however, swiftly have returned to body temperature of $37{ }^{\circ} \mathrm{C}$ in the following 50 seconds of salivary flow due to the temperature control of the superfusion chamber.

The results of the present experiments cannot be directly translated into the clinical situation. Nevertheless relative rather than absolute differences are of relevance, which were presented for the examined beverages at varying temperatures in a controlled experimental set-up. Out of evident ethical reasons no clinical data from in-vivo studies is available, which can be consulted for comparison. However, a few in-situ studies investigated the enamel loss of intra-orally worn enamel specimens. With this kind of set-up Wiegand and Attin [37] found an enamel loss of $2.2 \pm 1.3 \mu \mathrm{m}$ after 5 days of 6 extra-orally performed erosive impacts (immersion of specimens for $90 \mathrm{sec}$ in $100 \mathrm{ml}$ of Sprite). An other in-situ study [38]found an 
enamel loss of $2.37 \pm 1.11 \mu \mathrm{m}$ on intra-orally worn enamel specimens after 15 days with 4 erosive attacks/day ( $250 \mathrm{ml}$ of orange juice sipped over a period of $10 \mathrm{~min}$ ). In the same study [38] an in-vitro part was performed (agitation of specimens in $250 \mathrm{ml}$ of orange juice for 10 min, four times a day for 15 days), where $22.04 \pm 2.22 \mu \mathrm{m}$ of enamel loss was found.

The protocols of these studies are of course not comparable to the one used in the present investigation. However, the range of difference between the cited in-situ results and our findings seems to be in the range of 10-fold, therefore indicating clinical relevance.

The consumption temperature of erosive beverages varies greatly depending on the specific product, which ranges from acidic ice-chilled soft drinks to hot citrus lemonades. Cold remedies, which frequently contain citric acid, are often consumed at very high temperatures. The temperatures investigated in this study are typical for the consumption of the selected beverages. Orange juice, Coca-Cola Zero and Sprite Zero were tested at $5{ }^{\circ} \mathrm{C}$, a temperature corresponding to a drink freshly taken out of the refrigerator, and at $20^{\circ} \mathrm{C}$, which corresponds to a beverage stored at room temperature. Fruit teas were tested at $20{ }^{\circ} \mathrm{C}$ (room temperature) as well as $37{ }^{\circ} \mathrm{C}$ (body temperature), a standard temperature that is almost reached once a beverage is kept in the mouth for some time. The temperature of $55{ }^{\circ} \mathrm{C}$ was decided in a preexperiment, and was unisonous determined as highest temperature well bearable by a group of 5 testers. This also resembles the recommended optimal drinking temperature of approximately $57.8^{\circ} \mathrm{C}$ [39]. Citric acid, which served as control, was tested at all described temperatures.

The tested liquids differed greatly from each other with respect to type of acid, $\mathrm{pH}$, amount of titrable acid and calcium contents. This may explain the different erosive potentials of the liquids, being highest for citric acid, followed by orange juice, Coca-Cola Zero and Sprite Zero. Least erosive tooth substance loss was observed for the fruit teas. One reason for their low erosivity can be found in their acidic composition, containing not only citric but also the less potent malic and oxalic acid. Furthermore, both fruit teas had a relatively high calcium content due to their preparation with tap water, which presents a natural source of this mineral. The erosivity of the same fruit tea may therefore vary, depending on the regional water quality and mineral composition.

With the exception of orange juice, all beverages showed a tendency of a higher erosivity with rising temperatures. This can be explained by the common phenomenon that the rate of chemical reactions is accelerated with rising temperatures, such as the temperature-dependent calcium diffusion in bovine enamel [40]. It can however only be speculated why some of the tested drinks showed a significant temperature-dependent rise in erosivity, while the others 
did not. Since the erosive potential of acidic beverages is influenced by many different factors and their interaction, it may not be feasible to identify one single parameter as being responsible for this reaction.

It was not possible to pursue the experiment with human saliva due to three main reasons. First, the number and extent of experiments would have required an infeasible amount of saliva. Sufficient amounts of artificial saliva, however, can be prepared freshly with a consistent composition, which leads to a high degree of standardization [41]. Second, due to the duration of the tests that were performed at body temperature, human saliva would have decomposed and blocked the delicate tube system. Third, the composition of human saliva underlies great variation inter- and intra-individually, intraday, and according to the type and duration of stimulation [42]. Furthermore, individual salivary factors, such as mucin content, protein composition and viscosity are essential determinants of the saliva's protective effect against erosive lesions [43]. The use of different saliva donors would have added variance to the results and diverted from the main aim of the study. Nevertheless, certain properties such as formation of the acquired salivary pellicle, which has the ability to reduce the erosive destruction $[44,45]$, cannot be mimicked by artificial saliva. Additionally, mucin added to the artificial saliva has shown to block the pumping system of the artificial mouth. This fact needs to be mentioned as limitation in the interpretation and generalization of the present results.

Intact extracted human teeth are in great need for both teaching and research purposes [46]. Decreasing tooth extraction numbers, which are due to better hygiene awareness, as well as incorrect storage of extracted teeth have led to a shortage of extracted human teeth for these purposes [47]. The substitution of human with bovine enamel for research purposes is therefore common due to the limited number of intact extracted human teeth available. Human and bovine prismatic enamel show similarities in the surface ultrastructure of initial erosive lesions as well as in the progression thereof [48]. It was shown, however, that an erosive attack results in more enamel loss in bovine than in human teeth $[49,50]$. When keeping this fact in mind, bovine enamel can nevertheless be considered as suitable substitute for human enamel for demineralization and remineralization studies, especially when the relative effect of different agents is examined rather than absolute tissue loss [41], as it was the case in this study.

\section{Conclusions}

Not all investigated liquids showed a significant temperature-induced change in erosivity. Nevertheless, for some erosive beverages it is recommended to keep the consummation 
temperature as low as possible because of significantly higher erosive potential with higher temperatures. 


\section{References}

[1] T. Imfeld, Dental erosion. Definition, classification and links, Eur J Oral Sci. 104 (1996) 151-155.

[2] T. Jaeggi, A. Lussi, Prevalence, incidence and distribution of erosion, Monogr Oral Sci. 25 (2014) 55-73.

[3] H.M. van Rijkom, G.J. Truin, J.E. Frencken, K.G. König, M.A. van 't Hof, E.M. Bronkhorst, F.J. Roeters, Prevalence, distribution and background variables of smoothbordered tooth wear in teenagers in the hague, the Netherlands, Caries Res. 36 (2002) 147154.

[4] H. El Aidi, E.M. Bronkhorst, G.J. Truin, A longitudinal study of tooth erosion in adolescents, J Dent Res. 87 (2008) 731-735.

[5] A. Wiegand, J. Müller, C. Werner, T. Attin, Prevalence of erosive tooth wear and associated risk factors in 2-7-year-old German kindergarten children, Oral Dis. 12 (2006) $117-124$

[6] C. Tschammler, C. Müller-Pflanz, T. Attin, J. Müller, A. Wiegand, Prevalence and risk factors of erosive tooth wear in 3-6 year old German kindergarten children-A comparison between 2004/05 and 2014/15, J Dent. 52 (2016) 45-49.

[7] S. Basu, M. McKee, G. Galea, D. Stuckler, Relationship of soft drink consumption to global overweight, obesity, and diabetes: a cross-national analysis of 75 countries, Am J Public Health. 103 (2013) 2071-2077.

[8] D.C. Greenwood, D.E. Threapleton, C.E. Evans, C.L. Cleghorn, C. Nykjaer, C. Woodhead, V.J. Burley, Association between sugar-sweetened and artificially sweetened soft drinks and type 2 diabetes: systematic review and dose-response meta-analysis of prospective studies, Br J Nutr. 112 (2014) 725-734.

[9] Y. Ma, F.J. He, Y. Yin, K.M. Hashem, G.A. MacGregor, Gradual reduction of sugar in soft drinks without substitution as a strategy to reduce overweight, obesity, and type 2 diabetes: a modelling study, Lancet Diabetes Endocrinol. 4 (2016) 105-114.

[10] G. Velasquez-Melendez, M.D. Molina, I.M. Benseñor, L.O. Cardoso, M.J. Fonseca, A.D. Moreira, T.S. Pereira, S.M. Barreto, Sweetened Soft Drinks Consumption Is Associated with Metabolic Syndrome: Cross-sectional Analysis from the Brazilian Longitudinal Study of Adult Health (ELSA-Brasil), J Am Coll Nutr. 36 (2017) 99-107.

[11] K.E. Heller, B.A. Burt, S.A. Eklund, Sugared soda consumption and dental caries in the United States, J Dent Res. 80 (2001) 1949-1953.

[12] Hara A.T., Carvalho J.C., Zero D.T., Management D.E.A.I.C. (2015) in Dental Erosion and Its Clinical Management (factors. C.O.D.E.E., ed.) pp. 69-96, Springer International Publishing,

[13] A. Hasselkvist, A. Johansson, A.K. Johansson, Association between soft drink consumption, oral health and some lifestyle factors in Swedish adolescents, Acta Odontol Scand. 72 (2014) 1039-1046. 
[14] D.T. Zero, Etiology of dental erosion-extrinsic factors, Eur J Oral Sci. 104 (1996) 162177.

[15] A. Lussi, T. Jäggi, S. Schärer, The influence of different factors on in vitro enamel erosion, Caries Res. 27 (1993) 387-393.

[16] M.J. Larsen, B. Nyvad, Enamel erosion by some soft drinks and orange juices relative to their $\mathrm{pH}$, buffering effect and contents of calcium phosphate, Caries Res. 33 (1999) 81-87.

[17] B.T. Amaechi, S.M. Higham, W.M. Edgar, Factors influencing the development of dental erosion in vitro: enamel type, temperature and exposure time, J Oral Rehabil. 26 (1999) 624-630.

[18] N.X. West, J.A. Hughes, M. Addy, Erosion of dentine and enamel in vitro by dietary acids: the effect of temperature, acid character, concentration and exposure time, J Oral Rehabil. 27 (2000) 875-880.

[19] M. Eisenburger, M. Addy, Influence of liquid temperature and flow rate on enamel erosion and surface softening, J Oral Rehabil. 30 (2003) 1076-1080.

[20] M.E. Barbour, M. Finke, D.M. Parker, J.A. Hughes, G.C. Allen, M. Addy, The relationship between enamel softening and erosion caused by soft drinks at a range of temperatures, J Dent. 34 (2006) 207-213.

[21] I.D. Mandel, The functions of saliva, J Dent Res. 66 Spec No (1987) 623-627.

[22] I. Gedalia, A. Dakuar, L. Shapira, I. Lewinstein, J. Goultschin, E. Rahamim, Enamel softening with Coca-Cola and rehardening with milk or saliva, Am J Dent. 4 (1991) 120-122.

[23] A.T. Hara, D.T. Zero, The potential of saliva in protecting against dental erosion, Monogr Oral Sci. 25 (2014) 197-205.

[24] N.X. West, A. Maxwell, J.A. Hughes, D.M. Parker, R.G. Newcombe, M. Addy, A method to measure clinical erosion: the effect of orange juice consumption on erosion of enamel, J Dent. 26 (1998) 329-335.

[25] V.K. Järvinen, I.I. Rytömaa, O.P. Heinonen, Risk factors in dental erosion, J Dent Res. 70 (1991) 942-947.

[26] A. Lussi, Dental erosion clinical diagnosis and case history taking, Eur J Oral Sci. 104 (1996) 191-198.

[27] A.S. High, An unusual pattern of dental erosion. A case report, Br Dent J. 143 (1977) 403-404.

[28] M. Edwards, R.A. Ashwood, S.J. Littlewood, L.M. Brocklebank, D.E. Fung, A videofluoroscopic comparison of straw and cup drinking: the potential influence on dental erosion, Br Dent J. 185 (1998) 244-249. 
[29] R. Moazzez, B.G. Smith, D.W. Bartlett, Oral pH and drinking habit during ingestion of a carbonated drink in a group of adolescents with dental erosion, J Dent. 28 (2000) 395397.

[30] A.K. Johansson, P. Lingström, D. Birkhed, Comparison of factors potentially related to the occurrence of dental erosion in high- and low-erosion groups, Eur J Oral Sci. 110 (2002) 204-211.

[31] T.H. Grenby, Lessening dental erosive potential by product modification, Eur J Oral Sci. 104 (1996) 221-228.

[32] T. Attin, K. Meyer, E. Hellwig, W. Buchalla, A.M. Lennon, Effect of mineral supplements to citric acid on enamel erosion, Arch Oral Biol. 48 (2003) 753-759.

[33] J. Klimek, E. Hellwig, G. Ahrens, [Effect of plaque on fluoride stability in the enamel after amine fluoride application in the artificial mouth]., Dtsch Zahnarztl Z. 37 (1982) 836840 .

[34] A. Wiegand, S. Bliggenstorfer, A.C. Magalhaes, B. Sener, T. Attin, Impact of the in situ formed salivary pellicle on enamel and dentine erosion induced by different acids, Acta Odontol Scand. 66 (2008) 225-230.

[35] T. Attin, K. Becker, M. Roos, R. Attin, F. Paqué, Impact of storage conditions on profilometry of eroded dental hard tissue, Clin Oral Investig. 13 (2009) 473-478.

[36] R Core Team: A language and environment for statistical computing [Computer software]. R Foundation for Statistical Computing, Vienna, Austria (2015). URL https://www.R-project.org/

[37] A. Wiegand, T. Attin, Randomised in situ trial on the effect of milk and CPP-ACP on dental erosion., J Dent. 42 (2014) 1210-1215.

[38] J.A. Hughes, N.X. West, D.M. Parker, R.G. Newcombe, M. Addy, Development and evaluation of a low erosive blackcurrant juice drink in vitro and in situ. 1. Comparison with orange juice., J Dent. 27 (1999) 285-289.

[39] F. Brown, K.R. Diller, Calculating the optimum temperature for serving hot beverages., Burns. 34 (2008) 648-654.

[40] G.J. Flim, J. Arends, The temperature dependency of $45 \mathrm{Ca}$ diffusion in bovine enamel, Calcif Tissue Res. 24 (1977) 173-177.

[41] A. Wiegand, T. Attin, Design of erosion/abrasion studies - insights and rational concepts, Caries Res. 45 Suppl 1 (2011) 53-59.

[42] R.P. Shellis, C. Ganss, Y. Ren, D.T. Zero, A. Lussi, Methodology and models in erosion research: discussion and conclusions, Caries Res. 45 Suppl 1 (2011) 69-77.

[43] A.V. Nieuw Amerongen, C.H. Oderkerk, A.A. Driessen, Role of mucins from human whole saliva in the protection of tooth enamel against demineralization in vitro, Caries Res. 21 (1987) 297-309. 
[44] M. Hannig, M. Balz, Protective properties of salivary pellicles from two different intraoral sites on enamel erosion, Caries Res. 35 (2001) 142-148.

[45] M. Hannig, N.J. Hess, W. Hoth-Hannig, M. De Vrese, Influence of salivary pellicle formation time on enamel demineralization - an in situ pilot study, Clin Oral Investig. 7 (2003) 158-161.

[46] S.V. Sandhu, R. Tiwari, R.K. Bhullar, H. Bansal, R. Bhandari, T. Kakkar, R. Bhusri, Sterilization of extracted human teeth: A comparative analysis., J Oral Biol Craniofac Res. 2 (2012) 170-175.

[47] E.H. Mobarak, W. El-Badrawy, D.H. Pashley, H. Jamjoom, Effect of pretest storage conditions of extracted teeth on their dentin bond strengths., J Prosthet Dent. 104 (2010) 9297.

[48] J.H. Meurman, R.M. Frank, Progression and surface ultrastructure of in vitro caused erosive lesions in human and bovine enamel, Caries Res. 25 (1991) 81-87.

[49] D. Rios, H.M. Honório, A.C. Magalhães, A.C. Delbem, M.A. Machado, S.M. Silva, M.A. Buzalaf, Effect of salivary stimulation on erosion of human and bovine enamel subjected or not to subsequent abrasion: an in situ/ex vivo study, Caries Res. 40 (2006) 218223.

[50] T. Attin, F. Wegehaupt, D. Gries, A. Wiegand, The potential of deciduous and permanent bovine enamel as substitute for deciduous and permanent human enamel: Erosionabrasion experiments, J Dent. 35 (2007) 773-777. 


\section{Tables}

\section{Table 1}

Presentation of the $\mathrm{pH}$ values at all tested temperatures as well as the titrable acid and calcium content of the examined liquids. Main active acids were determined from the manufacturers' data.

Fruit tea 1 - Twinings of London ${ }^{\mathrm{TM}}$ fruit tea, fruit tea 2 - Lipton fruit tea Strawberry, Raspberry and Rhubarb

\begin{tabular}{|c|c|c|c|c|c|c|c|}
\hline \multirow[t]{2}{*}{ Liquid } & \multirow[t]{2}{*}{ Main active acid } & \multicolumn{4}{|c|}{ pH value at } & \multirow{2}{*}{$\begin{array}{c}\text { Titrable acid } \\
{[\mathrm{mmol} / \mathrm{L}]}\end{array}$} & \multirow{2}{*}{$\begin{array}{c}\begin{array}{c}\text { Calcium } \\
{[\mathrm{mmol} / \mathrm{L}]}\end{array} \\
20^{\circ} \mathrm{C}\end{array}$} \\
\hline & & $5^{\circ} \mathrm{C}$ & $20^{\circ} \mathrm{C}$ & $37^{\circ} \mathrm{C}$ & $55^{\circ} \mathrm{C}$ & & \\
\hline Citric acid & Citric acid & 2.68 & 2.70 & 2.76 & 2.68 & 15.1 & 0.00 \\
\hline Orange Juice & Citric acid & 3.9 & 3.88 & - & - & 80.0 & 1.75 \\
\hline Coca-Cola Zero & Phosphoric acid & 2.73 & 2.76 & - & - & 8.0 & 0.19 \\
\hline Sprite Zero & Citric acid & 3.08 & 3.01 & - & - & 31.3 & 0.23 \\
\hline Fruit tea 1 & Citric/Malic acid & - & 3.24 & 3.24 & 3.25 & 8.4 & 1.95 \\
\hline Fruit tea 2 & $\begin{array}{c}\text { Citric/Malic/Oxalic } \\
\text { acid }\end{array}$ & - & 3.31 & 3.32 & 3.33 & 8.7 & 1.93 \\
\hline
\end{tabular}




\section{Figure Legends}

\section{Figure 1}

Schematic illustration of the experimental procedure.

\section{Figure 2}

Enamel loss $[\mu \mathrm{m}]$ caused by the examined liquids at the tested temperatures. Identical superscript letters indicate that there was no significant difference within the liquid group at different temperatures ( $\mathrm{p}$-value of $\leq 0.001$, tested by pairwise posthoc comparisons calculated using Tukey's Honest Significance Difference Test). 


\section{Groups (G) with 12 enamel specimens each}

$5^{\circ} \mathrm{C}$

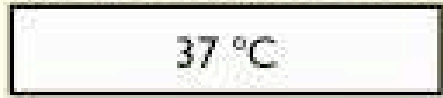

GI Citric Acid at $5^{\circ} \mathrm{C}$

GS Orange Juice at $5^{\circ} \mathrm{C}$

G7 Coke Zero at $5^{\circ} \mathrm{C}$

$G 9$ Sprite Zero at $5^{\circ} \mathrm{C}$ $20^{\circ} \mathrm{C}$

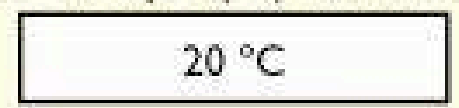

G2 Citric Acid at $20^{\circ} \mathrm{C}$

66 Orange fuice at $20^{\circ} \mathrm{C}$

68 Coke Zero at $20^{\circ} \mathrm{C}$

G10 Sprite Zero at $20^{\circ} \mathrm{C}$

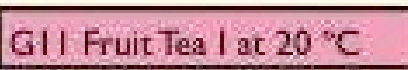

G14 Fruit Tea Il at $20^{\circ} \mathrm{C}$
G3 Citric Acid at $37^{\circ} \mathrm{C}$

$55^{\circ} \mathrm{C}$

G4 Citric Acid at $55^{\circ} \mathrm{C}$

G13 Fruit Tea I at $55^{\circ} \mathrm{C}$

GI2 fruit Tea I at $37^{\circ} \mathrm{C}$

G16 Fruic Tea II at $55^{\circ} \mathrm{C}$ tempered test liquid according to group allocation
$50 \mathrm{~min}$ artificial saliva

Remineralisation

$6 \mathrm{~h}$ artificial saliva 
